NASA Technical Memorandum 89927

AIAA-87-9262

\title{
Test Results of a 60 Volt Bipolar Nickel-Hydrogen Battery
}

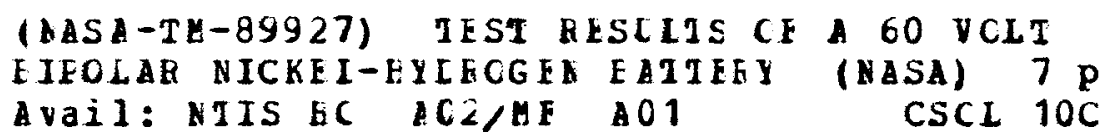

Russell L. Cataldo, Olga Gonzalez-Sanabria, Randall F. Gahn, Michelle A. Manzo, and Russel P. Gemeiner

Lewis Research Center

Cleveland, Ohio

Prepared for the

22nd Intersociety Energy Conversion Engineering Conference cosponsored by the AIAA, ANS, ASME, SAE, IEEE, ACS, and AIChE Philadelphia, Pennsylvania, August 10-14, 1987 


\title{
TEST RESULTS OF A 60 VOLT BIPOLAR NICKEL-HYDROGEN BATTERY
}

\author{
Robert L. Cataldo, Olga Gonzalez-Sanabria, Randall F. Gahn, \\ Michelle A. Manzo, and Russel P. Gemeiner \\ National Aeronautics and Space Administration \\ Lewis Research Center \\ Cleveland, Ohto 44135
}

\section{SUMMARY}

In July, 1986 a high voltage nickel-hydrogen battery was assembled at the NASA Lewis Research Center. This battery incorporated bipolar construction techniques to build a 50 cell stack with approximately $1.0 \mathrm{~A}$-hr capacity (C) and an open circuit voltage of $65 \mathrm{~V}$. The battery was characterized at both low and high current rates prior to pulsed and nonpulsed discharges. Pulse discharges of 5 and $10 \mathrm{C}$ were performed before placing the battery on over 1400, 40 percent depth-of-discharge, low-earth-orbit cycles. The successful demonstration of a high voltage bipolar battery in one containment vessel has advanced the technology to where nickel-hydrogen high voltage systems can be constructed of several modules instead of hundreds of individual cells.

\section{INTRODUCTION}

Bipolar nickel-hydrogen batteries that have been prevlously constructed at NASA Lewis and by Lewis Contractors have had a maximum of 10 cells. Alternatively, higher voltage battery designs were addressed because an opportunity for a flight battery was presented to the Energy Storage Branch, which has pioneered the majority of efforts in the bipolar nickel-hydrogen area. This mission required a $480 \mathrm{~V}$ battery with pulse discharge capabilities and relatively short cycle life (1000 cycles). The cycle life was derived from the mission scenarlo of several 7 day shuttle flights manifested two to three times during a 6 year period. Battery volume and footprint were design drivers that required a maximum of eight modules, or approximately $60 \mathrm{~V}$ per vesse 1.

The SEPAC (Space Experiments with Particle Accelerators) experiment had flown on Space Lab I aboard STS-9 in 1984. The battery used for that flight was a $4.0 \mathrm{~A}-\mathrm{hr}$, nickel-cadmium, 320 cell battery pack. A malfunctioning computer severely limited experiment operation to only two tests. When the returned battery was inspected, leaking terminals were found, precluding the battery from further service. Another battery was bullt with redesigned terminal seals, however, its age w1ll be in excess of 7 years when SEPAC is manifested again in 1991.

Discussions were carried out to define how NASA Lewis might help upgrade the experiment's power system. A bipolar nickel-hydrogen battery was considered an ideally suited technology for this application for several reasons: (1) 320 cell cans would be replaced by eight vessels, (2) pulse discharges required about $16 \mathrm{~A}$ (high rate for $4 \mathrm{~A}-\mathrm{hr}$ ), (3) low cycle life mission, and (4) fast recharge and deep discharge capability compared to the nickel-cadmium battery.

Therefore, SEPAC experiment requirements were used as a guideline in establishing the test conditions. The 40 cell module provided direction to assemble a 50 cell battery stack to determine battery performance relating to 
pulse discharging, cycle life, self-discharge, and anomalous behavior. The battery was constructed with hardware "on-hand" at the time. The hardware could accommodate a 2 by 2 in. electrode, which relates to a capacity of 1.0 A-hr. The scale-up difference of the test battery to the filght battery was not considered as a problem because bipolar designs are easily scaled with only minor design changes.

\section{BATTERY DESIGN}

Timely verification of a high voltage battery precluded any special design effort. Fortunately, a quantity of cell and battery components were on hand to construct a battery of the required voltage without procurement or fabrication delays. The bipolar plates avallable for timely construction were not edge coated with Tefion, which had been shown to inhibit or prevent shunt currents and eventual electrolyte transfer (ref. 2). However, construction proceeded as planned under the assumption that performance results would provide a "worst case" situation regarding shunt currents. Certain deliberate differences in cell to cell components existed which might have compromised battery level results, but would not affect the primary goal of verifying high voltage operation. Specific detalls of the design and construction techniques are given in detall in reference 1, which describes evaluation of the varlous design differences also evaluated in this battery.

\section{TEST PLAN}

The battery discharge power profile used for testing the battery was patterned after the anticipated shuttle experiment load profile. This profile consisted of pulse sequences of elther $1.0 \mathrm{sec}$ on, $4.0 \mathrm{sec}$ off, or $5.0 \mathrm{sec}$ on, $20 \mathrm{sec}$ off, with equal probability of occurring for a duration of $5 \mathrm{~min}$. A set of 5.0 min repetitions, called functional objectives, could occur a maximum of three times during the 30 min dark portion of the shuttle orbit. The power level requirements translates to approximately a 20 A discharge, which was about a $5 \mathrm{C}$ discharge rate on the $4.0 \mathrm{~A}-\mathrm{hr}$ flight battery. When three functional objectives are selected during one orbit a "worst-case" depth-ofdischarge (DOD) would be 25 percent or $1 \mathrm{~A}-\mathrm{hr}$. Nine functional objectives could be accomplished before recharging at 75 percent DOD.

The test plan consisted of constant current characterization, pulse tests, and 40 percent DOD low-earth-orbit cycling. The discharge rates used for the battery tests duplicated the flight battery's projected load requirements. In addition, open circuit stand perlods were performed to determine when and if shunt currents developed.

\section{RESULTS AND DISCUSSION}

Following battery assembly and insertion into the test chamber, three initialization cycles at $0.15 \mathrm{~A}$ at a $16 \mathrm{hr}$ charge and a $0.75 \mathrm{~A}$ discharge were performed. The capacity removed, to a cutoff of $40 \mathrm{~V}$, was $0.85 \mathrm{~A}-\mathrm{hr}$. During subsequent cycles battery capacity increased to about $1.0 \mathrm{~A}-\mathrm{hr}$, which was designated as the battery capacity (C) subsequently used for determining discharge rates.

Characterization tests were performed to generate a family of discharge curves relating battery capacity to current rates. Figure 1 displays this relationship for discharge rates of $0.25 \mathrm{~A},(\mathrm{C} / 4), 0.50 \mathrm{~A},(\mathrm{C} / 2), 1.0 \mathrm{~A},(\mathrm{C})$, 
$2.0 \mathrm{~A},(2 \mathrm{C}), 5.0 \mathrm{~A},(5 \mathrm{C})$, and $10 \mathrm{~A},(10 \mathrm{C})$; capacities removed to a $40 \mathrm{~V} 11 \mathrm{mit}$ were $1.06,1.05,1.03,1.0,0.76$, and $0.30 \mathrm{~A}-\mathrm{hr}$, respectively. Figure $2 \mathrm{dis}-$ plays battery discharge capacity utility factor (capacity removed at various rates as a percent of rated capacity) as a function of discharge rate, normalized at the $1.0 \mathrm{~A}$ rate. Th1s curve depicts projected utllity of the battery's capacity at various discharge rates.

Pulse discharges were performed at both 5.0 and $10.0 \mathrm{~A}$. Timing regimes of $1.0 \mathrm{sec}$ on $4.0 \mathrm{sec}$ off and $5.0 \mathrm{sec}$ on, $20 \mathrm{sec}$ off were used to evaluate pulse performance. There was no effect on pulse discharge capacity as a function of these pulse sequences. However, an increase in battery capacity utility was observed at both the 5.0 and $10.0 \mathrm{~A}$ pulse discharge rates compared to the equivalent nonpulsed rates. The greatest increase was seen in the $10.0 \mathrm{~A}$ rate. At this rate, a three-fold increase in delivered capacity was observed and is shown in figures 1 and 2 for comparison to the nonpulsed discharges. Only a 15 percent increase in capacity was seen in comparing 5.0 A pulsed to nonpulsed discharges. Several explanations can be offered for this observation: (1) the more severe 10.0 A rate depletes a greater amount of fons in the electrode pores, thus the relaxation time allows electrolyte concentration gradients to equalize in the thick electrode $(40 \mathrm{mils})$ and (2) more hydrogen gas flows into the electrode gas cavity during the relaxation period, thus maintaining a higher discharge voltage. Figure 3 shows a typical battery discharge voltage response to a $1.0 \mathrm{sec}$ on $4.0 \mathrm{sec}$ off $5.0 \mathrm{~A}$ pulse sequence. The voltage profile is typical for bipolar nickel-hydrogen batterles under pulse discharge load. However, a number of the more resistive cells were observed going negative which probably caused a decrease in avallable capacity.

Temperatures were also recorded in this passively cooled battery. The stainless steel vessel was at ambient room temperature of $23^{\circ} \mathrm{C}$. The heat removal mechanism was conduction and convection via the hydrogen gas (200 psi). The distance between the battery and the vessel wall was about $7 \mathrm{in}$. (18 cm), which presented a poor heat flow path. Figure 4 shows battery temperature increases for various constant current discharges. Reasonable temperatures were maintained up to the $1.0 \mathrm{~A}$ discharge rate, but higher discharge rates resulted in temperatures above $40^{\circ} \mathrm{C}$.

Open circuit stand tests ranging from about $60 \mathrm{hr}$ to several weeks were performed periodically to determine if any electrolyte bridging had occurred. Normal losses of 30 percent in capacity were observed during the 3 day stands. During stand times lasting a week or more, battery voltage dropped from 65 to $40 \mathrm{~V}$, indicating that perhaps some electrolyte films had developed across the noncoated bipolar plates causing parasitic losses in the form of shunt currents in affected cells.

Charge/discharge cycle tests were done to establish a life time and performance prediction for a high voltage bipolar battery. A one hour charge and half hour discharge regime was used in these tests to simulate projected mission operations. A discharge rate of 0.8 A resulted in removing $0.4 \mathrm{~A}-\mathrm{hr}$ or 40 percent DOD. Cycling continued for 1500 cycles, which exceeded the total expected cycle life of the mission. A decision was made to analyze individual components of the varlous cell groups rather than further cycling. The results of the analysis is reported in reference 1 . Figure 5 summarizes the cycling portion of the testing. A steady decline in end of discharge battery voltage was observed. This decline was primarlly seen in cells containing two layers of asbestos separator, while cells with zirconta cloth separators exhibited 
little voltage degradation. It was hypothesized that dry separators caused the decline and therefore electrolyte was added to three cells of the five cell asbestos group. The three cells significantly improved increasing battery voltage by about $4.0 \mathrm{~V}$ and recovering most of the voltage degradation.

\section{CONCLUSIONS}

A successful demonstration of a high voltage bipolar nickel-hydrogen battery was accomplished. The pulse and cycle performance showed that mission requirements could be satisfied with a generic design. Improvements could be anticipated by selecting the optimum combination of cell components and a specific design for the mission. Shunt currents, if present, did not limit cycle operation; however, electrolyte transfer can occur over time and hydrophobic treatment to certain components should eliminate this problem.

\section{REFERENCES}

1. Manzo, M.A., Gahn, R.F., Gonzalez-Sanabria, 0.0., Cataldo, R.L., and Gemeiner, R., "Component Variations and Their Effects on Bipolar Nicke1-Hydrogen Cell Performance," AIAA Paper 87-9260, NASA TM-89907, Aug. 1987 (to be presented at the 22nd IECEC).

2. Cataldo, R.L., "Life Cycle Test Results of a Bipolar Nickel-Hydrogen Battery," Energy for the Twenty-First Century (20th IECEC), Vol. 1, SAE, Warrendale, PA, pp. 1.346-1.351.

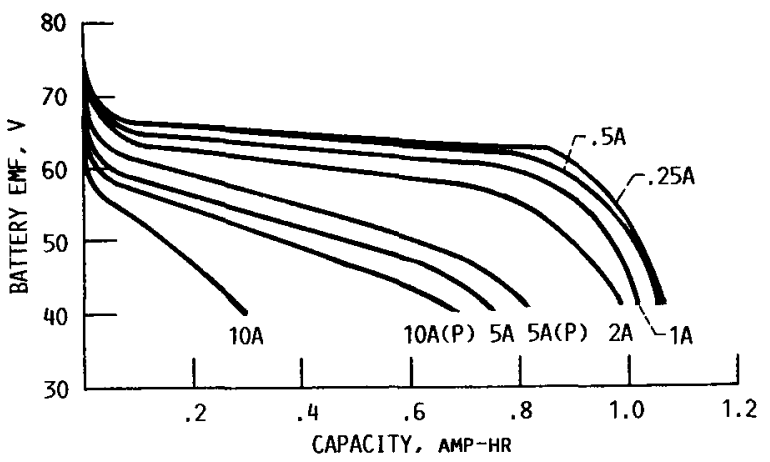

FIGURE 1. - BATTERY DISCHARGE CAPACITY VERSUS DISCHARGE RATE. 

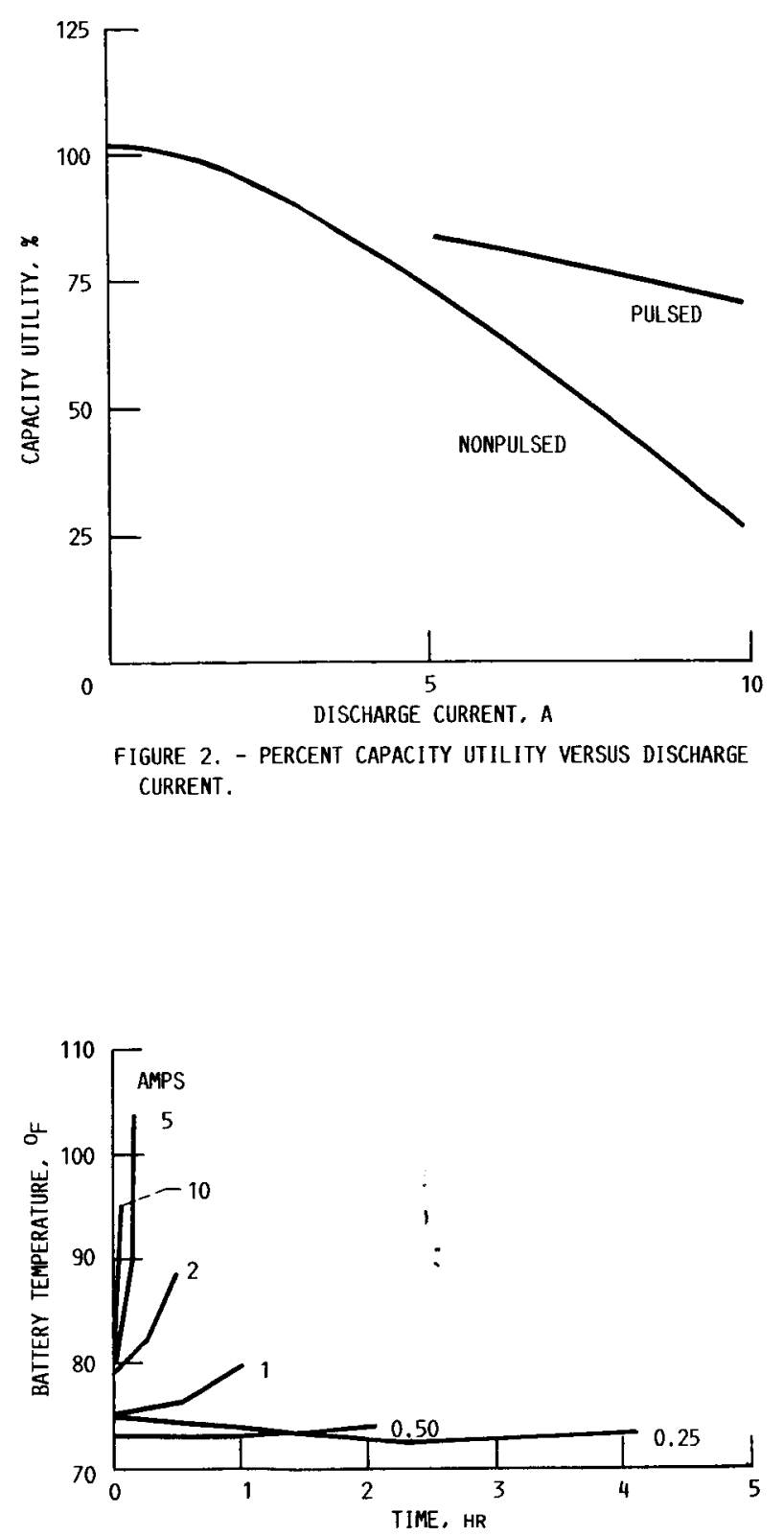

FIGURE 4. - BATTERY DISCHARGE TEMPERATURE FOR VARIOUS NONPULSED DISCHARGES.

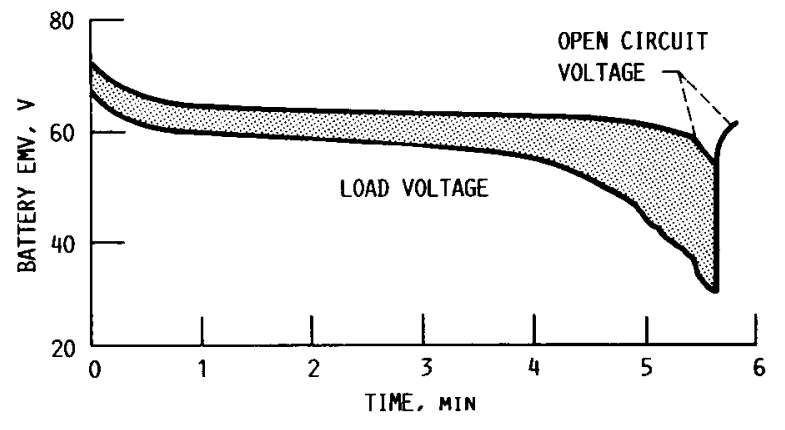

FIGURE 3. - BATTERY VOLTAGE RESPONSE TO A 5A PULSE REGIME OF $1.0 \mathrm{sEC}$ ON/4.0 SEC OFF.

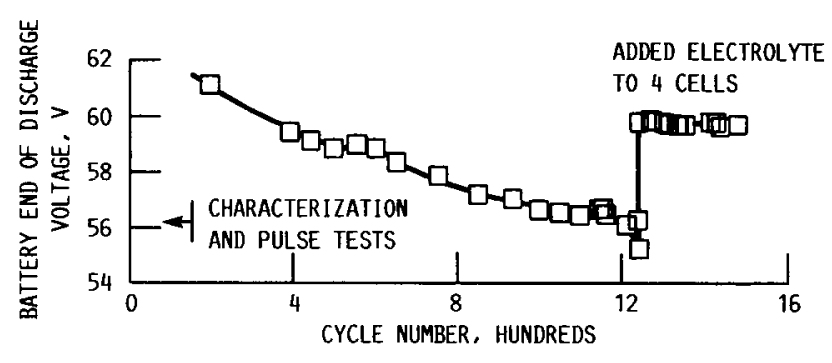

FIGURE 5. - BATTERY END OF DISCHARGE VOLTAGE ( 40 PERCENT DOD LEO REGIME) VERSUS CYCLE NUMBER. 


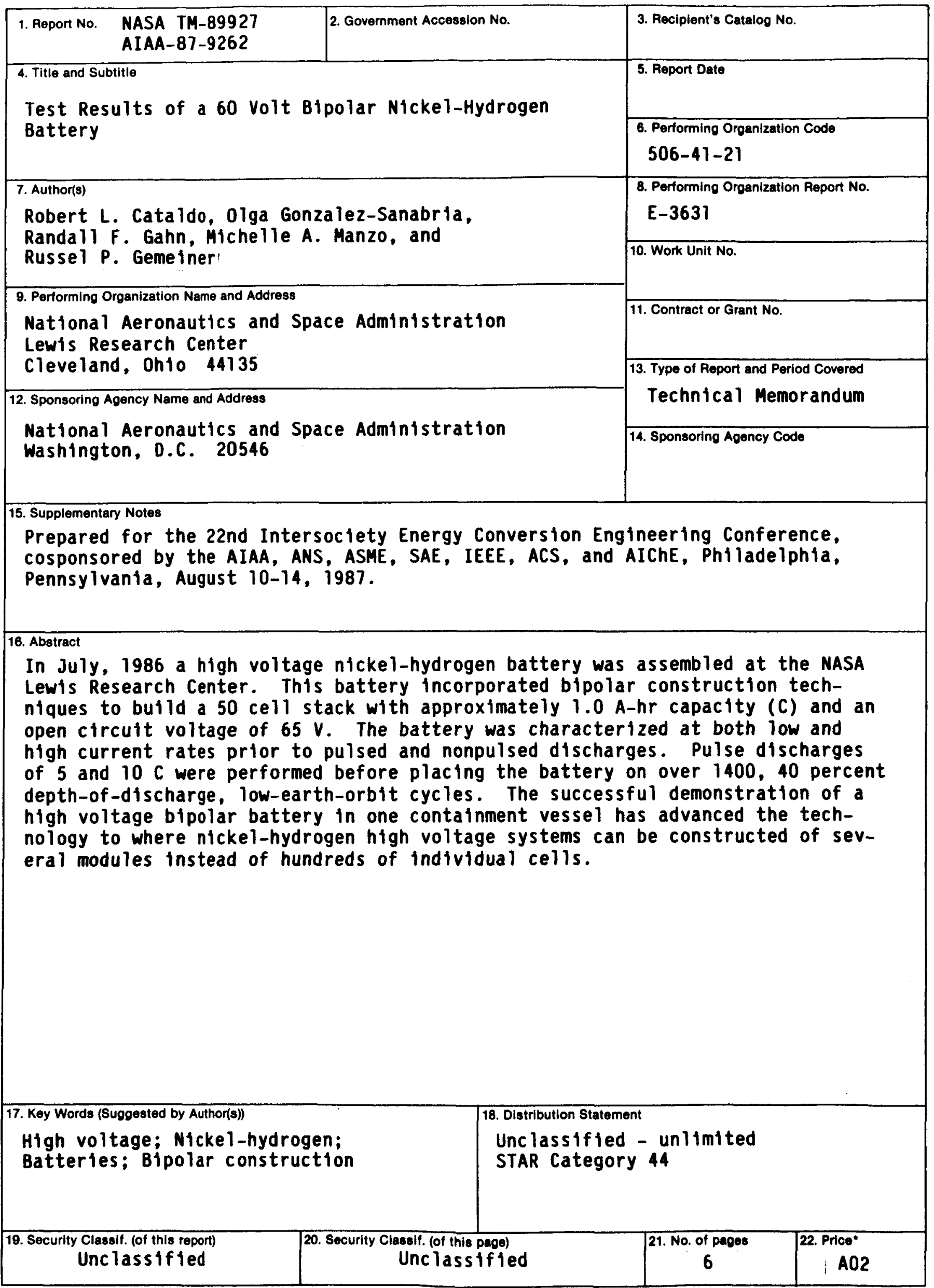

"For sale by the National Technical Information Service, Springfield, Virginia 22161 